\title{
Nitrogen fertilization changes the productivity and chemical composition of Brown and Golden flax grains
}

\section{Adubação nitrogenada altera a produtividade e a composição química de grãos de linhaça Marrom e Dourada}

\author{
Milene Puntel Osmari ${ }^{1}$; João Pedro Velho ${ }^{2 *}$; Marjana Chantal Waechter ${ }^{3}$; \\ Rodrigo Rutz ${ }^{4}$; Francilaine Eloise de Marchi ${ }^{5}$; Paulo Sérgio Gois Almeida ${ }^{2}$; \\ Ranulfo Combuca da Silva Júnior ${ }^{6}$; Geraldo Tadeu dos Santos ${ }^{7}$
}

\begin{abstract}
Nitrogen fertilization can be used to increase production for area, as well as to improve the grains nutritional value. The aim of this study was to evaluate the chemical composition of two linseed cultivars (Brown and Golden) submitted to increasing doses of nitrogen fertilization in a completely randomized design. The Brown and Golden flax sowing was in April 2014, using $40 \mathrm{~kg}$ of viable seeds $\mathrm{ha}^{-1}$ and $100 \mathrm{~kg} \mathrm{ha}^{-1}$ of diammonium phosphate (16-46-00) as fertilizer. It was evaluated the increasing doses of $\mathrm{N}$ fertilization in the cover: $0,50,100,150$ and $200 \mathrm{~kg}$ of $\mathrm{N} \mathrm{ha}^{-1}$, applied in the urea form. For the fatty acids (FA) analysis, a composite sample of each variety was performed for the treatment 0 and $200 \mathrm{~kg} \mathrm{~N} \mathrm{ha}^{-1}$. The composite samples were grounded in a multi-use mill with cooling jacket. The cooling was aimed to avoid the heating of the samples during their processing, in order to reduce the chances of FA profile alterations. The application of nitrogen positively influenced the production of grains and oil ha-1 of the cultivars, improved the Brown flax dry matter in vitro digestibility and the Golden flax neutral detergent fiber, ether extract and crude protein amounts. The cultivar Brown flax presented higher production of grains and oil ha- ${ }^{-1}$ when compared to Golden flax, which presented lower neutral detergent fiber, crude protein, total carbohydrates and higher amounts of ether extract. The Golden flax was nutritionally healthier, as it presented higher proportions of $\mathrm{C} 18: 3 \mathrm{n} 3$, unsaturated fatty acids, unsaturated/saturated fatty acids and hypocholesterolemic index. Both cultivars have potential ingredients to be used in animal feed, aiming to improve the quality of the final product.
\end{abstract}

Key words: Ether extract. Fatty acids. Linum usitatisimum. Oil. Production. Urea.

\section{Resumo}

A adubação nitrogenada pode ser utilizada para aumentar a produção por área, além de melhorar o valor nutricional dos grãos. Objetivou-se avaliar a composição bromatológica de duas cultivares de

1 Prof $^{\text {a }}$ Adjunta, Departamento de Zootecnia e Desenvolvimento Rural, Universidade Federal de Santa Catarina, UFSC, Florianópolis, SC, Brasil. E-mail: mileneosmari@yahoo.com.br

2 Profs. Associado, Departamento de Zootecnia e Ciências Biológicas, Universidade Federal de Santa Maria, UFSM, Campus de Palmeira das Missões, Palmeira das Missões, RS, Brasil. E-mail: velhojp@ufsm.br; pauloalmeida@smail.ufsm.br

3 Zootecnista, Cotripal Agropecuária Cooperativa, Panambi, RS, Brasil. E-mail: marjana@cotripal.com.br

4 Eng ${ }^{\circ}$ Agr ${ }^{\circ}$, Cotripal Agropecuária Cooperativa, Panambi, RS, Brasil. E-mail: rodrigo@cotripal.com.br

5 Prof ${ }^{\text {a }}$, Departamento de Zootecnia, UEM, Maringá, PR, Brasil. E-mail: francieloise@hotmail.com

6 Departamento de Zootecnia, UEM, Maringá, PR, Brasil. E-mail: ranulfo.gpes@gmail.com

7 Prof. Titular, Departamento de Zootecnia, Universidade Estadual de Maringá, UEM, Maringá, PR, Brasil. E-mail: gtsantos50@ gmail.com

* Author for correspondence 
linhaça (Marrom e Dourada) submetidas a níveis crescentes de adubação nitrogenada, em delineamento inteiramente casualizado. A semeadura da linhaça Marrom e Dourada ocorreram em abril de 2014, utilizando $40 \mathrm{~kg}$ de sementes viáveis ha $\mathrm{e}^{-1} \mathrm{e} 100 \mathrm{~kg} \mathrm{ha}^{-1}$ de fosfato diamônico (16-46-00) como fertilizante. Foram avaliadas as doses crescentes de adubação nitrogenada em cobertura: 0, 50, 100, 150 e $200 \mathrm{~kg}$ de $\mathrm{N} \mathrm{ha}^{-1}$, aplicadas na forma de ureia. Para a análise dos ácidos graxos (AG), foi realizada uma amostra composta de cada variedade para o tratamento 0 e $200 \mathrm{~kg} \mathrm{~N} \mathrm{ha}^{-1}$. As amostras compostas foram moídas em um moinho multiuso com refrigeração. $\mathrm{O}$ resfriamento teve como objetivo evitar o aquecimento das amostras durante o processamento, a fim de reduzir as chances de alterações no perfil do AG. A aplicação de nitrogênio influenciou positivamente a produção de grãos e óleo ha ${ }^{-1}$ das cultivares, melhorou a digestibilidade in vitro da matéria seca da linhaça e a quantidade de fibra em detergente neutro, do extrato etéreo e da proteína bruta. A cultivar Marrom apresentou maior produção de grãos e óleo ha-1 quando comparada a Dourada, que apresentou menor fibra em detergente neutro, proteína bruta, carboidratos totais e maior quantidade de extrato etéreo. A linhaça Dourada foi nutricionalmente mais saudável, pois apresentou maiores proporções de C18: 3 n3, ácidos graxos insaturados, ácidos graxos insaturados/saturados e índice hipocolesterolêmico. Ambas as cultivares possuem ingredientes potenciais para serem utilizadas na alimentação animal, visando melhorar a qualidade do produto final. Palavras-chave: Ácidos graxos. Extrato etéreo. Linum usitatisimum. Óleo. Produção. Ureia.

\section{Introduction}

The increasing world population and consequent increase in food consumption, including that of soybeans and corn grain, directs a need for the evaluation of alternative ingredients to be used in animal nutrition, especially in ruminant supplementation. Among these ingredients, those that are able to modify the fatty acid (FA) profile of meat and/or milk fat have been widely researched, improving nutritional quality, mainly by increasing the proportion of polyunsaturated fatty acids in the final product (HURTAUD et al., 2010; DOREAU; FERLAY, 2015; RADIS et al., 2016; SILVA et al., 2018).

Linseed (Linum usitatissimum L.) is one such ingredient because it contains a high oil content (40\%), comprising 55\% 18:3 n3 ( $\omega-3)$ (PETIT, 2010), and is also a source of dietary fiber and antioxidant compounds (PETIT, 2009). These characteristics have increased the conjugated linoleic acid (CLA) concentrations in milk from dairy cows (PETIT, 2015; FUKE; NORNBERG, 2017), which has been associated with reduced incidence of cardiovascular disease, hypercholesterolemia, and some types of cancer in humans (PETIT, 2009; DOREAU; FERLAY, 2015). Linseed fatty acids (FA) have also been shown to reduce enteric methane emissions from ruminants (MARTIN et al., 2016), decreasing greenhouse gas emissions by sequestering hydrogen from the rumen environment.

Fertilization is one of the main production factors that can interfere with linseed yield and quality (NALIUKHIN, 2016), and can also decrease the levels of stearic, oleic, and linoleic acids, and increase those of linolenic acid (AULAKH et al., 1989; YALCIN et al., 2011). However, few studies have investigated linseed production, chemical composition, and in vitro dry matter digestibility (IVDMD) under different doses of nitrogen $(\mathrm{N})$ fertilization. This study aimed to evaluate different $\mathrm{N}$ doses on the plant development, production, and chemical composition of Brown and Golden flax grains in southern Brazil.

\section{Materials and Methods}

\section{Cultivation}

Linseed was cultivated in a farm located in the municipality of Panambi, Rio Grande do Sul State, Brazil, $28^{\circ} 27^{\prime} 40^{\prime \prime}$ south and $53^{\circ} 27^{\prime} 53^{\prime \prime}$ west at 512 $\mathrm{m}$ altitude. The soil type is a typical Red Distroferric Latosol (STRECK et al., 2008). Soil was analyzed (Table 1) prior to the start of the experiment at the Soil Analysis Laboratory of the Universidade Federal 
de Santa Maria (UFSM), Santa Maria City, Rio Grande do Sul State, Brazil. The climate is the Cfa type, subtropical, with warm summers, rains that are well-distributed throughout the year, and an average temperature of $22^{\circ} \mathrm{C}$ (ALVARES et al., 2013).
The research was established in 50 plots, $5 \times 5 \mathrm{~m}$ each $\left(25 \mathrm{~m}^{2}\right)$, with 25 experimental units per flaxseed (Brown and Golden). The design was completely randomized, because the area was homogeneous.

Table 1. Soil characteristics measured before linseed establishment.

\begin{tabular}{ll}
\hline Items & Value \\
\hline Clay & $340 \mathrm{~g} \mathrm{~kg}^{-1}$ \\
$\mathrm{pH}$ & 5.5 \\
Phosphorus & $17.1 \mathrm{mg} \mathrm{dm}^{-3}$ \\
Potassium & $220 \mathrm{mg} \mathrm{dm}^{-3}$ \\
Organic matter & $37 \mathrm{~g} \mathrm{~kg}^{-1}$ \\
Aluminum & $0.0 \mathrm{cmol} \mathrm{dm}^{-3}$ \\
Calcium & $10.7 \mathrm{cmol} \mathrm{dm}^{-3}$ \\
Magnesium & $2.0 \mathrm{cmol} \mathrm{dm}^{-3}$ \\
Zinc & $6.0 \mathrm{mg} \mathrm{L}^{-1}$ \\
Copper & $9.4 \mathrm{mg} \mathrm{L}^{-1}$ \\
Sulfur & $20 \mathrm{mg} \mathrm{L}^{-1}$ \\
Boron & $0.4 \mathrm{mg} \mathrm{L}^{-1}$ \\
Cation exchange capacity & $17.7 \mathrm{cmol} \mathrm{dm}^{-3}$ \\
Base saturation & $752 \mathrm{~g} \mathrm{~kg}^{-1}$ \\
\hline
\end{tabular}

Brown and Golden flax were sown in April 2014, using $40 \mathrm{~kg}$ of viable seeds per hectare and $100 \mathrm{~kg} \mathrm{ha}^{-1}$ of diammonium phosphate (16-46-00) as fertilizer. Increasing doses of $\mathrm{N}$ fertilization in the cover were evaluated $(0,50,100,150$, and 200 $\mathrm{kg}$ of $\mathrm{N} \mathrm{ha}^{-1}$ ), which was applied in the form of urea. Half of the fertilizer was applied 30 days after sowing, comprising the stem emission phase, and the remainder was applied 46 days after sowing.

Due to the appearance of invasive plants, 100 $\mathrm{g} \mathrm{ha}^{-1}$ of iodosulfuron-methyl-sodium herbicide (p.a. $50 \mathrm{~g} \mathrm{~kg}^{-1}$ ) was applied at the beginning of the vegetative period. During the vegetative stage of the plants, $500 \mathrm{~mL} \mathrm{ha}^{-1}$ of a combination of fungicides was applied, containing Tebuconazole (p.a. $200 \mathrm{~g}$ $\mathrm{L}^{-1}$ ), Trifloxystrobin + Tebuconazole (p.a. $100 \mathrm{~g} \mathrm{~L}^{-1}$ $+200 \mathrm{~g} \mathrm{~L}^{-1}$ ), along with $5 \mathrm{~g} \mathrm{~kg}^{-1}$ of syrup, which was sprayed with mineral oil, in order to prevent foliar diseases.
During the full flowering stage, the heights $(\mathrm{cm})$ of 10 plants per plot were randomly evaluated. Linseed grains were harvested once the plants were mature. Three-square-meters of plants per plot were harvested manually using a scythe. Then, the plants were stored in clearly labelled raffia bags to separate the capsules from the grains through a $5 \mathrm{~mm}$ sieve. After separation, the grains were weighed, and the weights were extrapolated to the area of each plot for later estimation of grain yield per hectare $(\mathrm{kg})$.

\section{Laboratory tests}

The sampled grains were sent to the Centro Mesorregional em Excelência em Tecnologia do Leite, Região Noroeste, at the Experimental Farm of the Universidade Estadual de Maringá (UEM), Maringá, Paraná, Brazil for determination of dry matter (DM; method \#924.05), crude protein (CP) 
obtained from quantification of total $\mathrm{N}$ by the Kjeldahl technique (method \#920.87) multiplied by a fixed correction factor (6.25) (AOAC, 1990), neutral detergent fiber (NDF) (MERTENS, 2002), and ether extract (EE) using the Ankom XT15 equipment (Ankom Technology Corporation, Fairport, NY, USA).

The IVDMD was performed as described by Tilley and Terry (1963) and modified by Holden (1999), using the artificial rumen (DaisyII Fermenter ${ }^{\circledR}$, Ankom). The procedure was approved by the UEM Committee on Animal Use (CEUA/ UEM, \# 5430020316).

The total carbohydrates (TCHO) were calculated according to the equation (based on DM): TCHO $\left(\mathrm{g}^{\mathrm{kg}} \mathrm{kg}^{-1}\right)=100-\left(\operatorname{ash}\left(\mathrm{g} \cdot \mathrm{kg}^{-1}\right)+\mathrm{CP}\left(\mathrm{g} \cdot \mathrm{kg}^{-1}\right)+(\mathrm{EE}\right.$ g. $\left.\mathrm{kg}^{-1}\right)$ ) and the non-fibrous carbohydrates (NFC) as follows: NFC $\left(\mathrm{g}^{\mathrm{kg}} \mathrm{kg}^{-1}\right)=100-\left(\mathrm{NDF}\left(\mathrm{g} \cdot \mathrm{kg}^{-1}\right)+\mathrm{CP}\right.$ $\left(\mathrm{g} \cdot \mathrm{kg}^{-1}\right)+\mathrm{EE}\left(\mathrm{g} \cdot \mathrm{kg}^{-1}\right)+$ ash $\left.\left(\mathrm{g} \cdot \mathrm{kg}^{-1}\right)\right)$.

Subsequently, using the results obtained for $\mathrm{EE}$, the amount of oil present in the grains was estimated considering an oil extraction of $500 \mathrm{~g} \cdot \mathrm{kg}^{-1}$

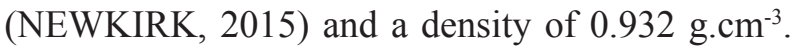
The production of oil per hectare was estimated $(\mathrm{kg}$ and $\mathrm{L}$ ) for each cultivar and $\mathrm{N}$ application dose.

FAs were analyzed using a composite sample of each variety for treatment with 0 and $200 \mathrm{~kg} \mathrm{~N} \mathrm{ha}^{-1}$. The composite samples were ground in a multi-use mill (model MA 630/1) with cooling jacket (Marconi Equipamentos para Laboratório Ltda, Piracicaba, São Paulo, Brazil). Samples were cooled to avoid heating during processing to reduce the chances of altering the FA profile.

After grinding, fat was extracted following the method described by Bligh and Dyer (1959), whereby the FAs were methylated according to Method 5509 (ISO, 1978), using KOH/methanol and $n$-heptane. Samples of FA esters $(1 \mu \mathrm{L})$ were quantified by gas chromatography (Trace GC Ultra, Thermo Scientific, USA) with an auto injector equipped with a flame ionizer and silica capillary column (Rt-2560, $100 \mathrm{~m}$ and $0.25 \mathrm{~mm} ; 0.20 \mu \mathrm{m}$ film thickness). The initial column temperature was $50^{\circ} \mathrm{C}$ for $4 \mathrm{~min}$, increasing $10^{\circ} \mathrm{C}$ per min up to $200^{\circ} \mathrm{C}$, where it was held for $15 \mathrm{~min}$. Then, the temperature was increased $20^{\circ} \mathrm{C}$ per minute up to $240^{\circ} \mathrm{C}$, where it was held for $8 \mathrm{~min}$. The injector and detector temperatures were each $250^{\circ} \mathrm{C}$. Gas flow was $400 \mathrm{~mL}$ synthetic air $\mathrm{min}^{-1}, 45 \mathrm{~mL}$ hydrogen $\mathrm{min}^{-1}$, and $45 \mathrm{~mL} \mathrm{~N} \mathrm{~min}{ }^{-1}$. The FA peaks were identified using pure methyl ester standards (Sigma, São Paulo, Brazil).

\section{Statistical analysis}

Data were submitted to analysis of variance through the PROC ANOVA procedure, which, when compared by nitrogen doses, was followed by a simple and polynomial second-order regression analysis in (SAS, 2004). To compare data between cultivars, regardless of the dose of fertilization employed, an analysis of variance was performed. A $2 \times 2$ factorial scheme was used to analyze the FA profile, considering two doses of $\mathrm{N}$ application and two linseed varieties. Significance was established at 0.05 in all analyses.

\section{Results and Discussion}

During the experimental period, the average minimum and maximum temperatures were 12.3 and $21.7^{\circ} \mathrm{C}$, respectively, which were similar to the values recorded over the previous 30 years. However, rainfall in the same period was $1,571 \mathrm{~mm}$, which was $37 \%$ higher than the historical average (Table 2); this may have interfered in the total light intensity received by the plants, decreasing their respiratory rates and consequently reducing photosynthetic capacity.

Soil characteristics, such as $\mathrm{pH}$, may also have influenced $\mathrm{N}$ uptake by plants, since this nutrient is better absorbed by flaxseed when the soil is $\mathrm{pH}$ 6.0 , which is higher than that presented in Table 1 
$(\mathrm{pH}=5.5)$ (HOCKING et al., 1987). In the same the applied fertilization, subsequently reducing $\mathrm{N}$ way, there was significant rainfall following $\mathrm{N}$ uptake by the plants. application, which may have caused leaching of

Table 2. Mean temperature $\left({ }^{\circ} \mathrm{C}\right)$ and rainfall $(\mathrm{mm})$ during the experimental period.

\begin{tabular}{|c|c|c|c|c|c|c|}
\hline \multirow{3}{*}{ Months } & \multicolumn{4}{|c|}{ Temperature $\left({ }^{\circ} \mathrm{C}\right)^{*}$} & \multicolumn{2}{|c|}{ Rainfall $(\mathrm{mm})^{*}$} \\
\hline & \multicolumn{2}{|l|}{2014} & \multicolumn{2}{|c|}{ Previous 30 years } & \multirow{2}{*}{2014} & \multirow{2}{*}{ Previous 30 years } \\
\hline & Minimum & Maximum & Minimum & Maximum & & \\
\hline April & 14.0 & 23.0 & 16.0 & 25.0 & 210.0 & 166.0 \\
\hline May & 12.0 & 20.0 & 12.0 & 20.0 & 283.0 & 163.0 \\
\hline June & 11.0 & 18.0 & 12.0 & 19.0 & 256.0 & 139.0 \\
\hline July & 9.0 & 19.0 & 10.0 & 18.0 & 208.0 & 145.0 \\
\hline August & 10.0 & 22.0 & 12.0 & 20.0 & 119.0 & 128.0 \\
\hline September & 14.0 & 23.0 & 13.0 & 22.0 & 335.0 & 177.0 \\
\hline October & 16.0 & 27.0 & 15.0 & 25.0 & 160.0 & 226.0 \\
\hline Sum & - & - & - & - & $1,571.0$ & $1,144.0$ \\
\hline
\end{tabular}

*Source: Temperature data are available at www.climatempo.com.br/climatologia/1406/panambi-rs. Rainfall data were obtained from a rain gauge installed at the experimental area.

The amount of nitrate ( $\left.\mathrm{NO}^{3-}\right)$ leached is directly dependent on the profile of water percolation in the soil. According to Cantarella (2007), the estimated nutrient displacement in Brazilian soils varies between 1 and $1.5 \mathrm{~mm}$ per $\mathrm{mL}$ of rainfall. Applying these values to the recorded rainfall during the $\mathrm{N}$ application period, it is estimated that fertilizer was leached $48 \mathrm{~cm}$ below the surface, which may have interfered in the absorption capacity of nutrients by the roots. Increasing $\mathrm{N}$ application provided linear and positive responses for height, grain yield $\mathrm{ha}^{-1}$, and oil yield ha ${ }^{-1}$ of the Brown flax $(\mathrm{P}<0.05$; Table $3)$, consistent with the findings of Dordas (2010), indicating that $\mathrm{N}$ fertilization does not only affect plant growth and development, but also modulates the absorption rate and $\mathrm{N}$-use efficiency.

Table 3. Mean values for production and chemical variables of Brown linseed.

\begin{tabular}{|c|c|c|c|c|c|c|c|c|}
\hline \multirow{2}{*}{ Items } & \multicolumn{5}{|c|}{ Fertilization doses $\left(\mathrm{kg} \mathrm{N} \mathrm{ha}^{-1}\right)$} & \multirow{2}{*}{ SE } & \multicolumn{2}{|c|}{$P-$ value } \\
\hline & 0 & 50 & 100 & 150 & 200 & & $\mathrm{~L}$ & $\mathrm{Q}$ \\
\hline \multicolumn{9}{|l|}{ Productivity } \\
\hline Height (cm) & 68.46 & 69.34 & 78.78 & 79.42 & 83.18 & 2.083 & $0.005^{1}$ & 0.78 \\
\hline Yield.ha' ${ }^{-1}(\mathrm{~kg})$ & 487.17 & 715.58 & 788.75 & 672.25 & 813.34 & 46.101 & $0.02^{2}$ & 0.17 \\
\hline Oil.ha- $^{-1}(\mathrm{~kg})$ & 138.45 & 205.57 & 232.15 & 189.55 & 244.04 & 8.560 & $0.03^{3}$ & 0.27 \\
\hline Oil.ha $^{-1}$ (liter) & 148.55 & 220.57 & 249.09 & 203.38 & 261.84 & 9.184 & $0.03^{4}$ & 0.27 \\
\hline \multicolumn{9}{|c|}{ Chemical characteristics Brown grain flax $\left(\mathrm{g} \mathrm{kg}^{-1}\right)$} \\
\hline Dry matter & 934.9 & 935.7 & 932.0 & 930.9 & 932.6 & 0.177 & 0.31 & 0.72 \\
\hline Ash & 56.1 & 48.5 & 46.0 & 46.5 & 45.1 & 0.387 & 0.56 & 0.25 \\
\hline
\end{tabular}


continuation

\begin{tabular}{lllllllll} 
NDF & 237.0 & 250.5 & 237.1 & 277.4 & 240.4 & 0.883 & 0.59 & 0.70 \\
Ether extract & 353.9 & 363.2 & 369.2 & 349.7 & 372.5 & 0.696 & 0.95 & 0.83 \\
Crude protein & 214.7 & 216.3 & 221.8 & 221.9 & 224.2 & 0.316 & 0.39 & 0.35 \\
Total carbohydrates & 375.4 & 372.0 & 363.1 & 381.8 & 358.1 & 0.687 & 0.96 & 0.66 \\
NFC* & 138.4 & 121.5 & 126.0 & 104.5 & 117.6 & 0.756 & 0.41 & 0.86 \\
IVDMD & 532.1 & 540.6 & 571.5 & 556.1 & 546.0 & 1.203 & 0.80 & $0.05^{5}$ \\
\hline
\end{tabular}

$\mathrm{NDF}=$ neutral detergent fiber; $\mathrm{NFC}=$ non-fibrous carbohydrates; IVDMD $=$ in vitro dry matter digestibility ${ }^{1} \hat{\mathrm{Y}}=67.275+0.0869$ $\mathrm{x}\left(\mathrm{r}^{2}=0.53\right) ;{ }^{2} \hat{\mathrm{Y}}=587.414+1.3936 \mathrm{x}\left(\mathrm{r}^{2}=0.44\right) ;{ }^{3} \hat{\mathrm{Y}}=169.883+0.4078 \times\left(\mathrm{r}^{2}=0.38\right) ;{ }^{4} \hat{\mathrm{Y}}=182.278+0.4376\left(\mathrm{r}^{2}=0.38\right) ;{ }^{5} \hat{\mathrm{Y}}=$ $51.963+0.0998 \mathrm{x}-0.000458 \mathrm{x}^{2}\left(\mathrm{r}^{2}=0.38\right)$.

Using literature reviews, Hocking et al. (1987) reported that flaxseed responds in a few ways to $\mathrm{N}$ fertilization, and the mineral effects seem to emerge as its concentration in the soil decreases over years of use. This hypothesis, which is associated with the proposal by Dordas (2010), confirms the contradictory results for $\mathrm{N}$ fertilization during flaxseed production; thus, further study in this area is required to validate the best $\mathrm{N}$ dosage, which in addition to increasing productivity, provides a better price-performance return.

In this way, Golden flax had linear and positive responses for height $(\mathrm{cm})$. However, it presented quadratic behavior for grain yield ha ${ }^{-1}$ and oil ha ${ }^{-1}$ ( $\mathrm{kg}$ and $\mathrm{L} ; \mathrm{P}=0.02$ ), with better responses under $80-82 \mathrm{~kg}$ of $\mathrm{N} \mathrm{ha}^{-1}$ (Table 4).

Table 4. Mean values for production and chemical variables of Golden linseed.

\begin{tabular}{|c|c|c|c|c|c|c|c|c|}
\hline \multirow{2}{*}{ Items } & \multicolumn{5}{|c|}{ Fertilization doses $\left(\mathrm{kg} \mathrm{N} \mathrm{ha}^{-1}\right)$} & \multirow{2}{*}{ SE } & \multicolumn{2}{|c|}{$P$-value } \\
\hline & 0 & 50 & 100 & 150 & 200 & & $\mathrm{~L}$ & Q \\
\hline \multicolumn{9}{|l|}{ Productivity } \\
\hline Height $(\mathrm{cm})$ & 60.66 & 60.78 & 69.62 & 71.82 & 68.62 & 2.088 & $0.002^{1}$ & 0.64 \\
\hline Yield ha' ${ }^{-1}(\mathrm{~kg})$ & 498.58 & 429.50 & 588.34 & 519.08 & 652.84 & 54.774 & 0.20 & $0.02^{2}$ \\
\hline Oil ha- $^{-1}(\mathrm{~kg})$ & 98.87 & 84.19 & 114.06 & 103.58 & 130.99 & 11.392 & 0.19 & $0.02^{3}$ \\
\hline Oil ha $^{-1}$ (liter) & 106.08 & 90.34 & 122.38 & 111.14 & 140.55 & 12.223 & 0.19 & $0.02^{4}$ \\
\hline \multicolumn{9}{|c|}{ Chemical characteristics Golden grain flax $\left(\mathrm{g} \mathrm{kg}^{-1}\right)^{* *}$} \\
\hline Dry matter & 946.6 & 946.7 & 946.4 & 943.7 & 939.8 & 0.247 & $0.003^{5}$ & 0.85 \\
\hline Ash & 48.5 & 51.1 & 44.5 & 43.9 & 39.8 & 0.371 & $0.03^{6}$ & 0.75 \\
\hline NDF & 227.9 & 248.2 & 234.7 & 238.7 & 225.2 & 0.736 & 0.49 & $0.003^{7}$ \\
\hline Ether extract & 395.2 & 387.8 & 388.6 & 395.4 & 400.7 & 0.484 & 0.46 & $0.042^{8}$ \\
\hline Crude protein & 204.5 & 208.8 & 213.0 & 213.3 & 224.8 & 0.509 & $0.001^{9}$ & 0.62 \\
\hline Total carbohydrates & 351.8 & 342.2 & 353.9 & 347.5 & 334.6 & 0.661 & 0.12 & 0.17 \\
\hline NFC & 123.9 & 109.4 & 119.2 & 108.8 & 109.5 & 1.051 & 0.57 & 0.31 \\
\hline IVDMD & 542.6 & 512.0 & 538.2 & 552.8 & 547.7 & 1.187 & 0.18 & 0.72 \\
\hline
\end{tabular}

$\mathrm{NDF}=$ neutral detergent fiber; $\mathrm{NFC}=$ non-fibrous carbohydrates; IVDMD $=$ in vitro dry matter digestibility. ${ }^{1} \hat{\mathrm{Y}}=57.740+0.0847$ $\mathrm{x}\left(\mathrm{r}^{2}=0.72\right) ;{ }^{2} \hat{\mathrm{Y}}=525.966-2.341 \mathrm{x}+0.0146 \mathrm{x}^{2}\left(\mathrm{r}^{2}=0.66\right) ;{ }^{3} \hat{\mathrm{Y}}=166.316-0.8481 \mathrm{x}+0.0052 \mathrm{x}^{2}\left(\mathrm{r}^{2}=0.70\right) ;{ }^{4} \hat{\mathrm{Y}}=178.451-0.9100$ $\mathrm{x}+0.0056 \mathrm{x}^{2}\left(\mathrm{r}^{2}=0.70\right) ;{ }^{5} \hat{\mathrm{Y}}=95.428-0.0083 \mathrm{x}\left(\mathrm{r}^{2}=0.69\right) ;{ }^{6} \hat{\mathrm{Y}}=5.317-0.0077 \mathrm{x}\left(\mathrm{r}^{2}=0.49\right) ;{ }^{7} \hat{\mathrm{Y}}=22.555+0.0578 \mathrm{x}-0.00032$ $\mathrm{x}^{2}\left(\mathrm{r}^{2}=0.76\right) ;{ }^{8} \hat{\mathrm{Y}}=39.462-0.0249 \mathrm{x}+0.00014 \mathrm{x}^{2}\left(\mathrm{r}^{2}=0.51\right) ;{ }^{9} \hat{\mathrm{Y}}=19.497+0.0154 \mathrm{x}\left(\mathrm{r}^{2}=0.78\right)$. 
Comparing the highest amount of $\mathrm{N}$ provided and the control treatment, the Golden flax presented an increase of $236 \mathrm{~g} \mathrm{~kg}^{-1}$ grains.ha-1 of production. Dordas (2010) also reported a significant increase $\left(380 \mathrm{~g} \mathrm{~kg}^{-1}\right)$ in the production of flax grains when using $\mathrm{N}$ fertilization. Santos et al. (2013) evaluated application of 0 to $600 \mathrm{~kg} \mathrm{~N}^{-1}$, and reported that application of $200 \mathrm{~kg}$ produced plants that were 75 $\mathrm{cm}$ high on average; this was higher than the Golden flax (Table 4) and Brown flax plants following applications up to $50 \mathrm{~kg} \mathrm{~N} \cdot \mathrm{ha}^{-1}$ (Table 3). Santos et al. (2013) also reported that plant height reduced from $200 \mathrm{~kg} \mathrm{~N}^{-1}$ to the maximum dose applied, since this nutrient influences plant growth until their needs are met.

Dordas (2010) evaluated the influence of $\mathrm{N}$ fertilization on flaxseed production and quality, and did not observe changes in the percentage of EE; however, there was a total increase in oil produced. A similar result can be seen in Table 3; although the EE of Brown flax was not influenced by $\mathrm{N}$ fertilization, the increase in yield resulted in a higher yield of oil ha-1 as the supply of $\mathrm{N}$ increased linearly.

Chemical data on Brown flaxseed indicated quadratic behavior of IVDMD with application of increasing $\mathrm{N}$ doses $(\mathrm{P}<0.05)$, with the best results obtained when approximately $109 \mathrm{~kg} \mathrm{~N}$ ha $^{-1}$ was applied (Table 3). This also suggests a correlation between the linseed IVDMD and CP concentration. The other nutrients were not influenced by $\mathrm{N}$ fertilization $(\mathrm{P}>0.05)$, especially the $\mathrm{EE}$ and $\mathrm{CP}$ doses, which are considered to be potential nutrients for increasing the energy density and nutritional value of ruminant diets.

Chemical variables of Golden flaxseed (Table 4) were influenced by the doses of $\mathrm{N}$ applied, with decreasing linear responses for DM and ash $(\mathrm{P}<$ 0.05). However, they favored linear increases in $\mathrm{CP}$ doses, where the higher $\mathrm{N}$ dosage provided an increase of $90 \mathrm{~g} \mathrm{~kg}^{-1}$ of the nutrient, when compared to the control treatment $(\mathrm{P}<0.05)$, increasing the
$\mathrm{N}$ availability to the plant, and permitting higher protein production.

The NDF and EE presented a quadratic response $(\mathrm{P}<0.05)$, with greater responses observed following application of 90.31 and $88.93 \mathrm{~kg} \mathrm{~N}$ $\mathrm{ha}^{-1}$, respectively, which was associated with the productivity responses, influencing Golden flaxseed oil production (Table 3). However, it is remains unclear if this increase would justify the investment in a high $\mathrm{N}$ dosage. Comparing the results between the variables, regardless of the $\mathrm{N}$ dose applied, Brown flax presented higher height and yield ha1, which improved the oil yield $\mathrm{ha}^{-1}(\mathrm{~kg}$ and $\mathrm{L}$ ), although the doses of EE were $32 \mathrm{~g} \mathrm{~kg}^{-1}$ lower than those of Golden flax (Table 4).

During the processing (milling) of Golden flax samples, the highest amount of oil presented by this cultivar was evident, which was also verified statistically following chemical analysis $(393.5 \times$ $\left.361.7 \mathrm{~g} \mathrm{~kg}^{-1}\right)$. These findings were in contrast to those reported by Barroso et al. (2014), who showed that the percentage EE was similar between Brown and Golden flaxseeds (342.5 $\mathrm{g} \mathrm{kg}^{-1}$ on average) based on evaluation of their chemical and functional properties.

The average EE value of was $393,6 \mathrm{~g} \mathrm{~kg}^{-1}$ (Table 4), which was higher than that reported by Bayrak et al. (2010) when evaluating flaxseed genotypes of different origins $\left(377.6 \times 297.5 \mathrm{~g} \mathrm{~kg}^{-1}\right.$, respectively), and similar to the value of $384.5 \mathrm{~g} \mathrm{~kg}^{-1}$ reported by Andruszczak et al. (2015) when evaluating the yield and quality of two flax cultivars under different agronomic management.

Compared with Golden flaxseed, the higher TCHO content of Brown flaxseed $\left(370 \mathrm{~g} \mathrm{~kg}^{-1}\right)$ was favored by its higher NDF and $\mathrm{CP}$ content $(\mathrm{P}<$ 0.05). Conversely, Golden flaxseed had a higher EE content than Brown flaxseed, but its productivity for the area was $230 \mathrm{~g} \mathrm{~kg}^{-1}$ lower, which did not favor an increase in oil production per hectare (Table $4)$. The superiority of Brown flaxseed observed is consistent with the findings of Barroso et al. (2014), 
who reported values of 280 and $225 \mathrm{~g} \mathrm{~kg}^{-1}$, for Brown and Golden flaxseed, respectively.

Thus, although the rainfall index had a negative influence on plant yield, under the conditions of the present study, the productivity for the area was a determinant factor for increasing the oil $\mathrm{ha}^{-1}$, regardless of the amount of EE presented by the cultivars. In this manner, management practices that maximize plant and oil production should be recommended, such as planting date and grain density assessments per hectare (ABD ELMOHSEN et al., 2013).

The Golden cultivar presented higher concentrations of all FA evaluated (Table 5; $\mathrm{P}<$ 0.05). However, both had a linolenic FA (C18:3 n3)

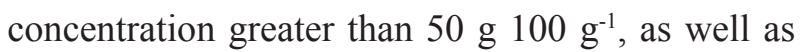
the values for oleic acid (C18:1) and linoleic acid (C18:2 n6), which were similar to those reported by
Bean and Leeson (2002) and Bayrak et al. (2010), when evaluating different flaxseed cultivars in Canada and Turkey, respectively.

Application of $200 \mathrm{~kg} \mathrm{~N}^{-1}$ reduced the concentration of $\mathrm{C} 16: 0$ by $2.24 \%$, C18:0 by $1.6 \%$, and SFA by $1.89 \%$. In contrast, the concentration of $\mathrm{C} 18: 1$ increased by $2.8 \%(\mathrm{P}<0.05$; Table 5$)$. In addition, there was a significant interaction between the flaxseed cultivar and the fertilization dose for C18: 2 n6; thus, with increasing $\mathrm{N}$ application, the FA concentration increased in the Brown flaxseed, but the inverse response was observed for C18:3 n3 (Table 5). Consistent with the findings of Aulakh et al. (1989), fertilization is one of the main production factors that can interfere with linseed yield and quality, and decrease the stearic acid content (Table 5).

Table 5. Mean fatty acid contents (g $100 \mathrm{~g}^{-1}$ of fatty acid) of Brown and Golden grains flax.

\begin{tabular}{|c|c|c|c|c|c|c|c|c|}
\hline \multirow{2}{*}{ Fatty Acids* } & \multicolumn{2}{|c|}{ Brown linseed } & \multicolumn{2}{|c|}{ Golden linseed } & \multirow{2}{*}{ SE } & \multicolumn{3}{|l|}{ P-value } \\
\hline & 0 & 200 & 0 & 200 & & Linseed Cultivar & $\mathrm{N}$ doses & LxN interaction \\
\hline C14:0 & 0.041 & 0.044 & 0.038 & 0.036 & 0.0014 & 0.0159 & 0.7335 & 0.2179 \\
\hline C16:0 & 6.329 & 6.254 & 5.264 & 5.093 & 0.0371 & $<0.001$ & 0.0296 & 0.2700 \\
\hline C16:1 & 0.068 & 0.066 & 0.049 & 0.045 & 0.0016 & 0.0002 & 0.1122 & 0.4785 \\
\hline C18:0 & 5.342 & 5.235 & 3.469 & 3.430 & 0.0238 & $<0.001$ & 0.0377 & 0.2289 \\
\hline C18:1 & 23.894 & 24.607 & 18.943 & 19.443 & 0.0567 & $<0.001$ & 0.0004 & 0.1341 \\
\hline $\mathrm{C} 18: 2 \mathrm{n} 6$ & 12.424 & 12.446 & 15.518 & 15.200 & 0.0388 & $<0.001$ & 0.0187 & 0.0119 \\
\hline $\mathrm{C} 18: 3 \mathrm{n} 3$ & 50.777 & 50.025 & 55.580 & 55.678 & 0.1131 & $<0.001$ & 0.0447 & 0.0198 \\
\hline SFA & 11.712 & 11.533 & 8.771 & 8.559 & 0.0475 & $<0.001$ & 0.0145 & 0.7606 \\
\hline PUFA & 87.163 & 87.144 & 90.090 & 90.366 & 0.0615 & $<0.001$ & 0.1043 & 0.0741 \\
\hline PUFA/SFA & 7.442 & 7.556 & 10.271 & 10.558 & 0.0579 & $<0.001$ & 0.0261 & 0.1956 \\
\hline$n-6 / n-3$ & 0.245 & 0.249 & 0.279 & 0.273 & 0.0010 & $<0.001$ & 0.3448 & 0.0063 \\
\hline Ih & 87.095 & 87.078 & 90.041 & 90.321 & 0.0615 & $<0.001$ & 0.0985 & 0.0733 \\
\hline $\mathrm{IH}$ & 6.370 & 6.298 & 5.302 & 5.129 & 0.0376 & $<0.001$ & 0.0308 & 0.2585 \\
\hline $\mathrm{h}: \mathrm{H}$ & 13.673 & 13.826 & 16.982 & 17.610 & 0.1099 & $<0.001$ & 0.0234 & 0.0988 \\
\hline
\end{tabular}

*C14:0 = myristic acid; C16:0 = palmitic acid; C16:1 = palmitoleic acid; C18:0 = stearic acid; C18:2 n6 = linoleic acids (linoleic acid + isomers); $\mathrm{C} 18: 3 \mathrm{n} 3=$ linolenic acids (linolenic acid + isomers); SFA = saturated fatty acid $(\mathrm{C} 14: 0+\mathrm{C} 16: 0+\mathrm{C} 18: 0)$; PUFA = polyunsaturated fatty acid $(\mathrm{C} 16: 1+\mathrm{C} 18: 1+\mathrm{C} 18: 2 \mathrm{n} 6+\mathrm{C} 18: 3 \mathrm{n} 3) ; \mathrm{n}-6: \mathrm{n}-3=\mathrm{C} 18: 2 \mathrm{n6} / \mathrm{C} 18: 3 \mathrm{n} 3$; Ih $=$ hypocholesterolemic index $(\mathrm{C} 18: 1+\mathrm{C} 18: 2+\mathrm{C} 18: 3) ; \mathrm{IH}=$ hypercholesterolemic index $(\mathrm{C} 14: 0+\mathrm{C} 16: 0) ; \mathrm{h}: \mathrm{H}=\mathrm{h}: \mathrm{H}$ index that considers the functional activity of FA in lipoprotein metabolism (Santos-Silva et al., 2002). 
Following the ingestion of linoleic ( $\omega-6)$ and linolenic $(\omega-3)$ FA by humans, eicosapentaenoic acid (EPA) and docosahexaenoic acid (DHA) are produced in liver cells. The functions of DHA include the formation, development, and functioning of the brain and retina. However, with advancing age, oxidative stress increases and brain DHA concentrations decrease, which may favor the occurrence of Alzheimer's and Parkinson's diseases. Thus, foods rich in $\omega-3$, such as flaxseed, can maintain constant DHA doses, since the $\omega-3$ conversion in EPA and DHA can range from 80 to $210 \mathrm{~g} \mathrm{~kg}^{-1}$ and from 0 to $90 \mathrm{~g} \mathrm{~kg}^{-1}$, respectively (MARTIN et al., 2006). It also presented superior functional quality when compared to the Brown flaxseed (Table 5), such as linoleic (C18:2 n6) and linolenic (C18:2 n3), which were increased by 19 and $11 \mathrm{~g} . \mathrm{kg}^{-1}$, respectively.

A diet rich in saturated fatty acids (SFAs) favors an increase in LDL cholesterol, which is associated with coronary disease (TVRZICKA et al., 2011; SIRI-TARINO et al., 2015). However, it is possible to decrease the proportion of SFAs in the final animal product through diet. In ruminants fed hay diets, these FAs represent, on average, 560 g. $\mathrm{kg}^{-1}$ of the total fat in cow's milk. In one study, linseed oil supplementation at $50 \mathrm{~g} \mathrm{~kg}^{-1}$ of DM was able to reduce the proportion of these components by up to $290 \mathrm{~g} \mathrm{~kg}^{-1}$ (CHILLIARD et al., 2007).

The total SFA, represented by the sum of C14:0, C16:0, and C18:0 (Table 5), was $255 \mathrm{~g}$ $\mathrm{kg}^{-1}$ lower for Golden flaxseed than for Brown flaxseed. In contrast, there was an increase of 35 $\mathrm{g} \mathrm{kg}^{-1}$ in the concentrations of polyunsaturated fatty acids (PUFAs) for the same cultivar, which favored its higher PUFA:SFA ratio $\left(280 \mathrm{~g} \mathrm{~kg}^{-1}\right)$, characterizing it as of better quality. Conversely, Barroso et al. (2014) demonstrated better quality for Brown flaxseed because of its high content of stearic acid (C18:0), which despite being an SFA, is atherogenic and can be rapidly converted to oleic acid (C18:1 n9).
The $\omega 6: \omega-3$ ratio seems to be of great importance, since smaller proportions tend to reduce the incidence of cardiovascular disease and thrombosis (TVRZICKA et al., 2011; SIRITARINO et al., 2015). In this context, the Brown flaxseed presented higher quality than the Golden flaxseed, due to its lower $\omega-6: \omega-3$ ratio $(0.247 \times$

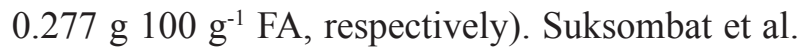
(2014) supplemented dairy cows with $688 \mathrm{~g} \mathrm{~d}^{-1}$ of flaxseed and observed a reduction of $12.3 \%$ in the milk $\omega-6: \omega-3$ ratio compared with supplementation with $300 \mathrm{~g} \mathrm{~d}^{-1}$ of flaxseed oil. In addition, the two forms of oleaginous supply improved the PUFA:SFA ratio in milk in relation to palm oil supplementation. These support flaxseed as a good source of feed for ruminants, which can be used as a functional feed to improve the nutrition of the final product.

The $\mathrm{h}: \mathrm{H}$ ratio is an index that considers the functional activity of FA in lipoprotein metabolism, and its type and quantity is related to a greater or lesser risk of cardiovascular disease. Thus, when this ratio is high, the feed oil or fat is nutritionally more adequate (SANTOS-SILVA et al., 2002). Golden flaxseed had a higher h:H ratio $(17,296$ $\times 13,749$ ) than Brown flaxseed, presenting a hypocholesterolemic index $220 \mathrm{~g} \mathrm{~kg}^{-1}$ lower than that of Brown flaxseed (Table 5), which in the present study makes it nutritionally healthier.

\section{Conclusion}

Brown and Golden flaxseed present higher productivity and oil production with increasing doses of nitrogen fertilization. The nitrogen doses improved the Brown flaxseed in vitro dry matter digestibility, as well the Golden flaxseed fiber, ether extract, and crude protein. Brown flaxseed is more productive than Golden flaxseed, even though it has a lower percentage of oil and poorer nutritional quality. Both cultivars possess potential ingredients for use in human and animal diets aiming to improve the quality of the final product as milk or meat. 


\section{Acknowledgements}

We acknowledge the Financiadora de Estudos e Projetos (FINEP) of the Ministério da Ciência e Tecnologia (MCT) for the financial resources made available in the Public Call MCT/FINEP/CTINFRA- CAMPI REGIONAL - 01/2010, which enabled the Universidade Federal de Santa Maria, Campus de Palmeira das Missões to establish the Laboratório de Estudos sobre Interface PlantaAnimal. This study was financed in part by the Coordenação de Aperfeiçoamento de Pessoal de Nível Superior, Brasil (CAPES), Finance Code 001 for granting a postdoctoral fellowship on PNPD modality to the lead author.

\section{References}

ABD EL-MOHSEN, A. A.; ABDALLAH, A. M.; MAHMOUD, G. O. Optimizing and describing the influence of planting dates and seeding rates on flax cultivars under Middle Egypt region conditions. World Essays Journal, Jhang Road, v. 1, n. 4, p. 142-152, 2013.

ALVARES, C. A.; STAPE, J. L.; SENTELHAS, P. C.; GONÇALVES, J. L. M.; SPAROVEK, G. Köppen's climate classification map for Brazil. Meteorologische Zeitschrift, Berlin, v. 22, n. 6, p. 711-728, 2013. DOI: 10.1127/0941-2948/2013/0507

ANDRUSZCZAK, S.; GAWLIK-DZIKI, U.; KRASKA, P.; KWIECIŃSKA-POPPE, E.; RÓŻYŁO, K.; PAŁYS, E. Yield and quality traits of two linseed (Linum usitatissimum L.) cultivars as affected by some agronomics factors. Plant, Soil and Environment, Slezská, v. 61 , n. 6 , p. 247-252, 2015. DOI: 10.17221/120/2015PSE

ASSOCIATION OF OFFICIAL ANALYTICAL CHEMISTS - AOAC. Official methods of analysis. $15^{\text {th }}$ ed. Arlington: AOAC, 1990.

AULAKH, M. S.; PASRICHA, N. S.; AZAD, A. S.; AHUJA, K. L. Response of linseed (Linum usitatissimum L.) to fertilizer nitrogen, phosphorus and sulphur, and their effect on the removal of soil sulphur. Soil Use and Management, Oxford, v. 5, n. 4, p. 194-198, 1989. DOI: 10.1111/j.1475-2743.1989.tb00783.x

BARROSO, A. K. M.; TORRES, A. G.; CASTELOBRANCO, V. N.; FERREIRA, A.; FINOTELLI, P. V.; FREITAS, S. P.; ROCHA-LEÃO, M. H. M. Linhaça marrom e dourada: propriedades químicas e funcionais das sementes e dos óleos prensados a frio. Ciência Rural, Santa Maria, v. 44, n. 1, p. 181-187, 2014. DOI: 10.1590/ S0103-84782014000100029

BAYRAK, A.; KIRALAN, M.; IPEK, A.; ARSLAN, N.; COSGE, B.; KHAUWAR, K. M. Fatty acid composition of linseed (Linum usitatissimum L.) genotypes of different origen cultivated in Turkey. Biotechnology \& Biotechnological Equipment, v. 24, n. 2, p. 1836-1842, 2010. DOI: 10.2478/V10133-010-0034-2

BEAN, L. D.; LEESON, S. Fatty acid profiles of 23 samples of flaxseed collected from commercial feed mills in Ontario in 2001. Journal of Applied Poultry Research, Athens, v. 11, n. 2, p. 209-2011, 2002. DOI: 10.1093/ japr/11.2.209

BLIGH, E. G.; DYER, W. J. A rapid method of total lipid extraction and purification. Canadian Journal of Biochemistry and Physiology, Ottawa, v. 37, n. 8, p. 911917, 1959. DOI: 10.1139/059-099

CANTARELLA, H. Nitrogênio. In: NOVAIS, R. F.; ALVAREZ, V. H.; BARROS, N. F.; FONTES, R. L. F.; CANTARUTTI, R. B.; NEVES, J. C. L. (Ed.). Fertilidade do solo. Viçosa, MG: Sociedade Brasileira de Ciência do Solo, 2007. p. 375-470.

CHILLIARD, Y.; GLASSER, F.; FERLAY, A.; BERNARD, L.; ROUEL, J.; DOREAU, M. Diet, rumen biohydrogenation and nutritional quality of cow and goat milk. European Journal Lipid Science Technology, Weinheim, v. 109, n. 9, p. 828-855, 2007. DOI: $10.1002 /$ ejlt.200700080

DORDAS, A. C. Variation of physiological determinants of yield in linseed in response to nitrogen fertilization. Industrial Crops and Products, v. 31, n. 3, p. 455-465, 2010. DOI: $10.1016 /$ j.indcrop.2010.01.008

DOREAU, M.; FERLAY, A. Linseed: a valuable feedstuff for ruminants. Oilseeds and Fats, Crops and Lipids, Les Ulis, v. 22, n. 6, p. 1-9, 2015. DOI: 10.1051/ocl/2015042

FUKE, G.; NORNBERG, J. L. (). Systematic evaluation on the effectiveness of conjugated linoleic acid in human health. Critical Reviews in Food Science and Nutrition, v. 57, n. 1, p. 1-7,2017. DOI: 10.1080/10408398.2012.716800

HOCKING, P. J.; RANDALL, P. J.; PINKERTON, A. Mineral nutrition of linseed and fiber flax. Advances in Agronomy, San Diego, v. 41, n. 1, p. 221-296, 1987. DOI: $10.1016 / \mathrm{S} 0065-2113(08) 60806-8$

HOLDEN, L. A. Comparison of methods of in vitro dry matter digestibility for ten feeds. Journal of Dairy Science, Champaign, v. 82, n. 8, p. 1791-1794, 1999. DOI: 10.3168/jds.S0022-0302(99)75409-3 
HURTAUD, C.; FAUCON, F.; COUVREUR, S.; PEYRAUD, J. L. Linear relationship between increasing amounts of extrused linseed in dairy cow diet and milk fatty acid composition and butter properties. Journal of Dairy Science, Champaign, v. 93, n. 4, p. 1429-1443, 2010. DOI: $10.3168 /$ jds.2009-2839

International Organization for Standarzation - ISO. Animal and vegetable fats and oils - Preparation of methyl esteres of fatty acids. Genebra: ISO, 1978. Method ISO 5509. p. 01-06.

MARTIN, C. A.; ALMEIDA, V. V.; RUIZ, M. R.; VISENTAINER, J. E. L.; MATSHUSHITA, M.; SOUZA, N. E.; VISENTER, J. V. Ácidos graxos poli-insaturados ômega-3 e ômega-6: importância e ocorrência em alimentos. Revista de Nutrição, Campinas, v. 19, n. 6, p. 761-770, 2006. DOI: 10.1590/S141552732006000600011

MARTIN, C.; FERLAY, A.; MOSONI, P.; ROCHETTE, Y.; CHILLIARD, Y.; DOREAU, M. Increasing linseed supply in dairy cow diets based on hay or corn silage: Effect on enteric methane emission, rumen microbial fermentation, and digestion. Journal of Dairy Science, Champaign, v. 99, n. 5, p. 3445-3456, 2016. DOI: $10.3168 /$ jds.2015-10110

MERTENS, D. R. Gravimetric determination of amylasetreated neutral detergent fiber in feeds with refluxing in beakers or crucibles: collaborative study. Journal of AOAC International, Arlington, v. 85, n. 6, p. 1217-1240, 2002.

NALIUKHIN, A. N. Plants diagnostics of nitrogen nutrition of flax. Russian Agricultural Sciences, Moscow v. 42, n. 6, 416-419, 2016. DOI: 10.3103/ S1068367416060215

NEWKIRK, R. Flax feed industry guide. Winnipeg: Flax Canada, 2015. 24 p.

PETIT, H. V. Antioxidants and dairy production: the example of flax. Revista Brasileira de Zootecnia, Viçosa, v. 38, p. 352-361, 2009. Numero Especial. DOI: 10.1590/ S1516-35982009001300035

PETIT, H. V. Milk production and composition, milk fatty acid profile, and blood composition of dairy cows fed different proportions of whole flaxseed in the first half of lactation. Animal Feed Science and Technology, Amsterdam, v. 205, n. 7, p. 23-30, 2015.

PETIT, H. V. Review: feed intake, milk production and milk composition of dairy cows fed flaxseed. Canadian Journal of Animal Science, Ottawa, v. 90, n. 2, p. 115127,2010 .
RADIS, A. C.; MACEDO, F. de A. F. de; MORA, N. H. A. P.; ALCALDE, C. R.; VISENTAINER, J. V.; BOEING, J. S. Fatty acid profile in meat of culling ewes in different feedlot periods fed diets containing levels of inclusion of linseed. Semina: Ciências Agrárias, Londrina, v. 37, n. 4, 2321-2330, 2016. DOI: 10.5433/1679-0359.2016v37n4Supl1p2321

SANTOS, R. F.; ZORNITA, N.; BARICATTI, R. A.; CARPISKI, M.; SANTOS, M. A. Nitrogênio no cultivo da linhaça dourada (Linus usitatissimum). Acta Iguazu, Cascavel, v. 2, n. 3, p.73-83, 2013.

SANTOS-SILVA, J.; BESSA, R. J. B.; MENDES, I. A. The effect of genotype, feeding system and slaughter weight on the quality of light lamb. II - Fatty acid composition of meat. Livestock Science, Amsterdam, v. 77, n. 2, p. 187-194, 2002.

SILVA, B. C. da M.; RODRIGUEZ, N. M.; MORENZ, M. J. F.; GOMIDE, C. A. de M.; MARTINS, C. E.; PACIULLO, D. S. C.; GAMA, M. A. S.; LOPES, F. C. F. Fatty acid composition of milk from Holstein x Gyr cows grazing on marandu grass supplemented with concentrate containing sunflower oil. Semina: Ciências Agrárias, Londrina, v. 39, n. 6, p. 2581-2596, 2018. DOI: $10.5433 / 1679-0359.2018 v 39 n 6 p 2581$

SIRI-TARINO, P. W.; CHIU, S.; BERGERON, N.; KRAUSS, R. M. Saturated fats versus polyunsaturated fats versus carbohydrates for cardiovascular disease prevention and treatment. Annual Review of Nutrition, Palo Alto, v. 35, n. 1, p. 517-543, 2015. DOI: 10.1146/ annurev-nutr-071714-034449

STATISTICALANALYSIS SYSTEM - SAS. SAS/STAT User guide, version 9.1.2. Cary: SAS Institute Inc., 2004.

STRECK, E. V.; KÄMPF, N.; DALMOLIN, R. S. D.; KLAMT, E.; NASCIMENTO, P. C.; SCHNEIDER, P.; GIASSON, E.; PINTO, L. F. S. Solos do Rio Grande do Sul. 2. ed. Porto Alegre: Emater, 2008. 222 p.

SUKSOMBAT, W.; THANH, L. P.; MEEPROM, C.; MIRATTANAPHRAI, R. Effects of linseed oil or whole linseed supplementation on performance and milk fatty acid composition of lactating dairy cows. AsianAustralasian Journal of Animal Science, Seoul, v. 27, n. 7, p. 951-959, 2014. DOI: 10.5713/ajas.2013.13665

TILLEY, J. M. A.; TERRY, R. A. A two-stage techniques for digestion of forage crops. Grass and Forage Science, Oxford, v. 18, n. 2, p. 104-111, 1963. DOI: 10.1111/ j.1365-2494.1963.tb00335.x

TVRZICKA, E.; KREMMYDA, L. S.; STANKOVA, B.; ZAK, A. Fatty acids as biocompounds: their role in human metabolism, health and disease - a review. Part 
1: classification, dietary sources and biological functions. Biomedical papers of the Medical Faculty of the University Palacký, Olomouc, Czechoslovakia, Prague, v. 155, n. 2, p. 117-130, 2011. DOI: 10.5507/bp.2011.038
YALCIN, H.; ÖZTÜRK, I.; TULUKÇU, E.; SAGDIC, O. Influence of the harvesting year and fertilizer on the fatty acid composition and some physicochemical properties of linseed (Linum usitatissimum L.). Journal of Consumer Protection and Food Safety, v. 6, p. 197202, 2011. DOI: 10.1007/s00003-010-0631-x 